\section{Chemical treatment and size of corn seed on physiological and sanitary quality during storage}

\author{
Karen Marcelle de Jesus Silva ${ }^{1 *}$ (D) Renzo Garcia Von Pinho ${ }^{1}{ }^{(\mathbb{D}}$, Édila Vilela \\ de Resende Von Pinho ${ }^{1}$ (D) Renato Mendes de Oliveira² ${ }^{(\mathbb{D})}$, Heloísa Oliveira \\ dos Santos' ${ }^{1}$, Thomas Simas Silva' (iD)
}

\begin{abstract}
The aim of this study was to investigate the effect of treatment with insecticides and fungicides on the physiological quality of corn seeds, classified in sizes, in different periods of storage. Seeds of the hybrid BM915 PRO, classified in two sizes (CH20/64 and CH24/64), were treated with a mixture of carbendazim + thiram (Derosal Plus ${ }^{\circledR}$ ), pirimiphos methyl (Actellic ${ }^{\circledR}$ ), deltamethrin (K-obiol ${ }^{\circledR}$ ), and water (standard treatment). In addition to the standard treatment adopted by the company, treatments with clothianidin (Poncho ${ }^{\circledR}$ ), thiamethoxam $\left(\right.$ Cruizer $\left.^{\circledR}\right)$, and fipronil (Shelter ${ }^{\circledR}$ ) were added to the spray mixture. The seeds were stored in a non-climate-controlled environment in multi-ply paper packages. The physiological quality of the seeds was evaluated every ninety days over a period of 270 days by the germination test, cold test, and accelerated aging. Sanitary quality was also evaluated through the Blotter test. The physiological quality of seeds of the hybrid BM915 PRO is maintained up to ninety days of storage, regardless of the chemical treatment used and the size of the seeds. The addition of the insecticide to the standard treatment used in chemical seed treatment does not affect the action of the fungicides on the fungi in the seeds.
\end{abstract}

Index terms: Zea mays, seed vigor, conservation, sanitary treatment, industrial treatment.

\section{Tratamento químico e tamanho da semente de milho na qualidade fisiológica e sanitária durante o armazenamento}

RESUMO: Objetivou-se verificar a interferência do tratamento com inseticidas e fungicidas sobre a qualidade fisiológica de sementes de milho, classificadas em dois tamanhos, em diferentes períodos de armazenamento. Sementes do híbrido BM915 PRO, classificadas em dois tamanhos ( $\mathrm{CH} 20 / 64$ e $\mathrm{CH} 24 / 64)$, foram tratadas com calda caracterizada pela mistura de Carbendazim + Thiram (Derosal Plus ${ }^{\circledR}$ ), Deltametrina $\left(\right.$ Actellic $^{\circledR}$ ), Pirimifós metílico (K-obiol ${ }^{\circledR}$ ) e água (tratamento padrão). Além do tratamento padrão adotado pela empresa, foram acrescentados à mistura da calda tratamentos com clotianidina (Poncho ${ }^{\circledR}$ ), tiametoxam (Cruizer ${ }^{\circledR}$ ) e fipronil (Shelter ${ }^{\circledR}$ ). As sementes foram armazenadas em ambiente não climatizado em embalagens de papel multifoliado. A qualidade fisiológica das sementes foi avaliada, a cada noventa dias, por um período de 270 dias por meio do teste de germinação, teste de frio e envelhecimento acelerado. Foi avaliada, ainda, a qualidade sanitária por meio do Blotter test. Concluiu-se que a qualidade fisiológica das sementes do híbrido BM915 PRO é mantida até os noventa dias de armazenamento, independente do tratamento químico utilizado e do tamanho das sementes. A adição do inseticida ao tratamento padrão utilizado no tratamento químico das sementes não afeta a ação dos fungicidas sobre os fungos presentes nestas.

Termos para indexação: Zea mays, vigor de sementes, conservação, tratamento sanitário, tratamento industrial.
Journal of Seed Science, v.42, e202042010, 2020

http://dx.doi.org/10.1590/2317$1545 v 42219569$
${ }^{*}$ Corresponding author
E-mail: karen_marcelle@hotmail.com

Received: $2 / 6 / 2019$. Accepted: 11/26/2019.

${ }^{1}$ Universidade Federal de Lavras.

${ }^{2}$ Universidade Estadual de Montes

Claros. 


\section{INTRODUCTION}

Seed is one of the main inputs in agriculture, and its quality is one of the primary factors for establishing any crop (Nunes et al., 2009). Seed quality can be affected by different biotic and abiotic factors, such as chemical treatment and storage conditions. Seed treatment has been used as a tool for protecting seeds in the field and in storage for the purpose of maintaining physiological quality, and it is a valuable method for controlling and/or preventing pest and pathogen attacks. Lack of this initial protection can have a direct impact on yield.

Chemical treatment consists of incorporating artificially developed chemical products on the seeds. This modality has been increasingly adopted by farmers since it is easy to perform and can be practiced in a controlled environment through the ease of uniformly distributing small amounts of products in growing areas, through reduced need for complementary applications of pesticides on developing crops, and through its low relative cost, which, even so, provides significant increases in final yield. Some factors affect the performance of the seed chemical treatment, such as type of seed, physical and physiological condition of the seed lot to be treated, seed size, product formulation, active ingredient, and application rate of the product (Machado, 2000).

Inadequate application of chemical products on seeds can increase risks of deterioration of their physiological quality, due to possible phytotoxic effects. Salgado and Ximenes (2013) evaluated the effect of treatment of maize seeds with insecticides in different storage periods and concluded that seed treatment with insecticide and storage affect seed germination. According to these authors, the interaction of seed treatment and storage affect the number of ungerminated seeds.

In contrast, the advantages of using seed with protection against external biological agents, such as fungi, insects, nematodes, etc. are well-known (Tonin et al., 2014). In Brazil, nearly $100 \%$ of hybrid maize seeds are treated with fungicides and insecticides in the seed industry for pest control in storage; $35 \%$ are treated with insecticides, and the rest receive insecticide application on the farm property itself (Nunes, 2016).

The fact that chemical treatment of maize seeds is a widely used practice before storage and near the time of sowing highlights the importance of conducting studies on the chemical products used for treatment, as well as their effect on the quality of seeds under storage.

Thus, the aim of this study was to investigate the effect of insecticide and fungicide treatment on the physiological quality of maize seeds classified in two sizes in different storage periods.

\section{MATERIAL AND METHODS}

The experiment was conducted in the Seed Sector of the Department of Agriculture of the Universidade Federal de Lavras (UFLA) in the municipality of Lavras, MG, Brazil.

The seeds used were of the maize hybrid BM915 PRO, with a flat shape, classified in two sizes (CH20/64 and CH24/64), granted by the Hellix Sementes company, from the 2015/2016 crop season.

The seeds were treated manually using plastic bags, in which the seeds and the chemical products were mixed in a uniform manner.

The seeds were treated with a spray mixture composed of insecticides and fungicides adopted by the production company, characterized by a mixture of carbendazim + thiram (Derosal Plus ${ }^{\circledR}$ ), pirimiphos methyl (Actellic ${ }^{\circledR}$ ), deltamethrin $\left(\mathrm{K}\right.$-obio $\mathrm{I}^{\circledR}$ ), and water (standard treatment) (Table 1). In addition to the standard treatment adopted by the company, the insecticides clothianidin (Poncho ${ }^{\circledR}$ ), thiamethoxam $\left(\right.$ Cruizer $\left.^{\circledR}\right)$, and fipronil (Shelter ${ }^{\circledR}$ ) were separately added to the spray mixture (Table 2). The spray volume used was the same for all the treatments. The insecticide application rates were those recommended by the manufacturers.

After the treatments, the seeds were placed in multi-ply paper bags, similar to those used by the production company, kept on wooden pallets, and stored in a non-climate-controlled environment. The environment referred to is a shed covered with galvanized steel roofing that is closed, located in the Seed Sector of the Universidade Federal de Lavras. The 
Table 1. Products used in composition of the standard treatment applied in the seed treatment and their respective application rates.

\begin{tabular}{cccc}
\hline Commercial product & Active ingredient & Class & Application rate of the active ingredient \\
\hline \multirow{2}{*}{ Derosal Plus } & carbendazim & Fungicide & $2.04 \mathrm{~g}$ a.i. $/ 100 \mathrm{~kg}$ of seed \\
& thiram & Fungicide & $4.76 \mathrm{~g}$ a.i. $/ 100 \mathrm{~kg}$ of seed \\
K-obiol $^{\circledR}$ & deltamethrin & Insecticide & $0.02 \mathrm{~g} \mathrm{a.i.} / 100 \mathrm{~kg}$ of seed \\
Actellic $^{\circledR}$ & pirimiphos methyl & Insecticide & $0.04 \mathrm{~g} \mathrm{a.i.} / 100 \mathrm{~kg}$ of seed \\
\hline
\end{tabular}

Table 2. Insecticides and application rates used in the seed treatments.

\begin{tabular}{ccc}
\hline Commercial product & Active ingredient & Application rate of the active ingredient \\
\hline Poncho $^{\circledast}$ & clothianidin & $210 \mathrm{~g}$ a.i. $/ 100 \mathrm{~kg}$ of seed \\
Cruizer $^{\circledast}$ & thiamethoxam & $210 \mathrm{~g}$ a.i. $/ 100 \mathrm{~kg}$ of seed \\
Shelter $^{\circledast}$ & fipronil & $62.5 \mathrm{~g}$ a.i. $/ 100 \mathrm{~kg}$ of seed \\
\hline
\end{tabular}

storage period began on May $25^{\text {th }}, 2016$ and ended on February $16^{\text {th }}, 2017$. During this period, temperatures ranged from $18{ }^{\circ} \mathrm{C}$ to $25.9^{\circ} \mathrm{C}$, and relative humidity within the storage location oscillated from $44 \%$ to $77 \%$.

Seed quality was evaluated at the beginning of the storage period and every ninety days, over a period of 270 days, through the tests described as follows.

Germination test: performed using germitest paper moistened with water in the amount of 2.5 times the dry weight of the paper, with four replications of fifty seeds in a germinator at $25{ }^{\circ} \mathrm{C}$. The first germination count was performed at four days after setting up the test, and the last, at seven days. Classification was made of normal seedlings, abnormal seedlings, and dead seeds, and the result was expressed in percentage of abnormal seedlings (Brasil, 2009b).

Cold test without soil: performed using germitest paper as a substrate, moistened with water in the amount of 2.5 times the dry weight of the paper, with four replications of fifty seeds in the form of rolls, similar to the germination test. The rolls were placed in plastic bags and kept in a chamber regulated to $10^{\circ} \mathrm{C}$ for seven days. After that period, the rolls were removed from the plastic bags and kept in a seed germinator regulated to $25^{\circ} \mathrm{C}$, for four days (Krzyzanowski et al., 1999). After that, the seedlings were evaluated, considering only normal seedlings, following the criteria adopted for the germination test (Brasil, 2009b).

Accelerated aging: gerbox transparent plastic boxes $(11.5 \times 11.5 \times 3.5 \mathrm{~cm})$ were used with screens inside, on which the seeds were distributed so as to form a uniform layer. At the bottom of each plastic box, $40 \mathrm{~mL}$ of distilled water was added, establishing an environment with $100 \%$ relative humidity. The boxed were closed and kept in an aging chamber (BOD type) at $42^{\circ} \mathrm{C}$ for 72 hours. After that period, the seeds were removed from the chamber and the germination test was performed, evaluating normal seedlings on the fifth day after setting up the test.

Seed health test: the sanitary quality of the seeds was determined through the filter paper method (blotter test), following the method of the Manual de Análise Sanitária de Sementes (Brasil, 2009a). Eight replications of fifty seeds were used per treatment. The seeds were placed on three sheets of previously sterilized and moistened filter paper in Petri dishes that were transparent and with lids. The samples were cooled in a freezer for $24 \mathrm{~h}$. After that, the samples were incubated at $20 \pm 2{ }^{\circ} \mathrm{C}$ for a period of ten days under a regime of twelve hours of light. At the end of this period, the seeds were individually examined under a stereomicroscope at a resolution of 30-80 X. Results were expressed in percentage of occurrence of fungi.

The experiment was conducted in a completely randomized experimental design in a $2 \times 4 \times 4$ factorial arrangement, with four replications, constituted by two classifications regarding seed size $(\mathrm{CH} 20 / 64$ and $\mathrm{CH} 24 / 64)$, four chemical treatments, and four storage periods. 
Data were analyzed through the Sisvar statistical program (Ferreira, 2011). The Tukey test at 5\% probability was used to compare the means, and a regression study was performed for the storage period factor.

\section{RESULTS AND DISCUSSION}

\section{Germination test}

There was no difference among the chemical treatments used up to 180 days of storage for seeds of size $\mathrm{CH} 24 / 64$ (Table 3). Nevertheless, in seeds of size $\mathrm{CH} 20 / 64$ under the treatment with thiamethoxam at 0 days and clothianidin at ninety days of storage, results inferior to the other treatments were observed. From 180 days of storage on, seeds of size $\mathrm{CH} 20 / 64$ did not show statistical differences among the treatments.

In spite of loss of quality over the storage period (Figure 1), seeds of the hybrid BM915 PRO maintained germination percentages above the minimum standard established by the Ministry of Agriculture for commercialization (85\% germination). It is noteworthy that the use of the standard treatment resulted in smaller reductions in seed physiological quality in relation to the others.

Similar results were observed by Rosa et al. (2012) and Tonin et al. (2014) upon using hybrid maize seeds treated with different insecticides. The authors found loss of physiological quality when the seeds were treated with thiamethoxam and stored in a natural environment for 180 and 270 days.

Mariucci et al. (2018) observed reduction in germination of hybrid maize seeds under treatments with insecticides, fungicides, and different combinations of inoculants after 45 days of storage.

Lorenzetti et al. (2014) found that maize seeds treated with fipronil did not lose physiological quality after a 42-day storage period, which corroborates the results obtained in the present study.

For the results of germination, the addition of the active compound thiamethoxam to the standard treatment used by the production company resulted in loss of physiological quality of maize seeds.

Various authors affirm that the quality of stored seeds of hybrid maize treated with insecticides is affected not only by the chemical product used in the seed treatment, but also by the genotype and by the conditions of the storage environment (Bittencourt et al., 2000; Marcos-Filho, 2005; Rosa et al., 2012; Tonin et al., 2014). These assertions corroborate the results of this study.

Table 3. Germination percentage of seeds of the maize hybrid BM915 PRO in accordance with storage periods (SP), seed size, and chemical treatments.

\begin{tabular}{|c|c|c|c|c|c|}
\hline \multirow[b]{2}{*}{ SP (days) } & \multirow[b]{2}{*}{ Seed size } & \multicolumn{4}{|c|}{ Treatment } \\
\hline & & *Standard treat. & $\begin{array}{l}\text { *Standard treat. + } \\
\text { clothianidin }\end{array}$ & $\begin{array}{c}\text { *Standard treat. + } \\
\text { thiamethoxam }\end{array}$ & $\begin{array}{l}\text { *Standard treat.+ } \\
\text { fipronil }\end{array}$ \\
\hline \multirow{2}{*}{0} & $\mathrm{CH} 20 / 64$ & $96 \mathrm{Aa}$ & $95 \mathrm{Aa}$ & $88 \mathrm{Bb}$ & $97 \mathrm{Aa}$ \\
\hline & $\mathrm{CH} 24 / 64$ & $97 \mathrm{Aa}$ & $98 \mathrm{Aa}$ & $97 \mathrm{Aa}$ & $99 \mathrm{Aa}$ \\
\hline \multirow{2}{*}{90} & $\mathrm{CH} 20 / 64$ & $96 \mathrm{Aa}$ & $90 \mathrm{Bb}$ & $97 \mathrm{Aa}$ & $95 \mathrm{Aa}$ \\
\hline & $\mathrm{CH} 24 / 64$ & $98 \mathrm{Aa}$ & $97 \mathrm{Aa}$ & $98 \mathrm{Aa}$ & $95 \mathrm{Aa}$ \\
\hline \multirow{2}{*}{180} & $\mathrm{CH} 20 / 64$ & $93 \mathrm{Ba}$ & $96 \mathrm{Aa}$ & $93 \mathrm{Aa}$ & $92 \mathrm{Ba}$ \\
\hline & $\mathrm{CH} 24 / 64$ & $98 \mathrm{Aa}$ & $95 \mathrm{Aa}$ & $96 \mathrm{Aa}$ & $96 \mathrm{Aa}$ \\
\hline \multirow{2}{*}{270} & $\mathrm{CH} 20 / 64$ & $90 \mathrm{Ba}$ & $91 \mathrm{Aa}$ & $89 \mathrm{Aa}$ & $89 \mathrm{Ba}$ \\
\hline & $\mathrm{CH} 24 / 64$ & $97 \mathrm{Aa}$ & $90 \mathrm{Ab}$ & $92 \mathrm{Aab}$ & $95 \mathrm{Aab}$ \\
\hline CV (\%) & \multicolumn{5}{|c|}{3.09} \\
\hline \multicolumn{6}{|c|}{$\begin{array}{l}\text { Mean values followed by the same uppercase letter in the column and lowercase letter in the row within each storage period do not differ fror } \\
\text { each other by the Tukey test at } 5 \% \text { significance. } \\
\text { *Standard treatment. }\end{array}$} \\
\hline
\end{tabular}



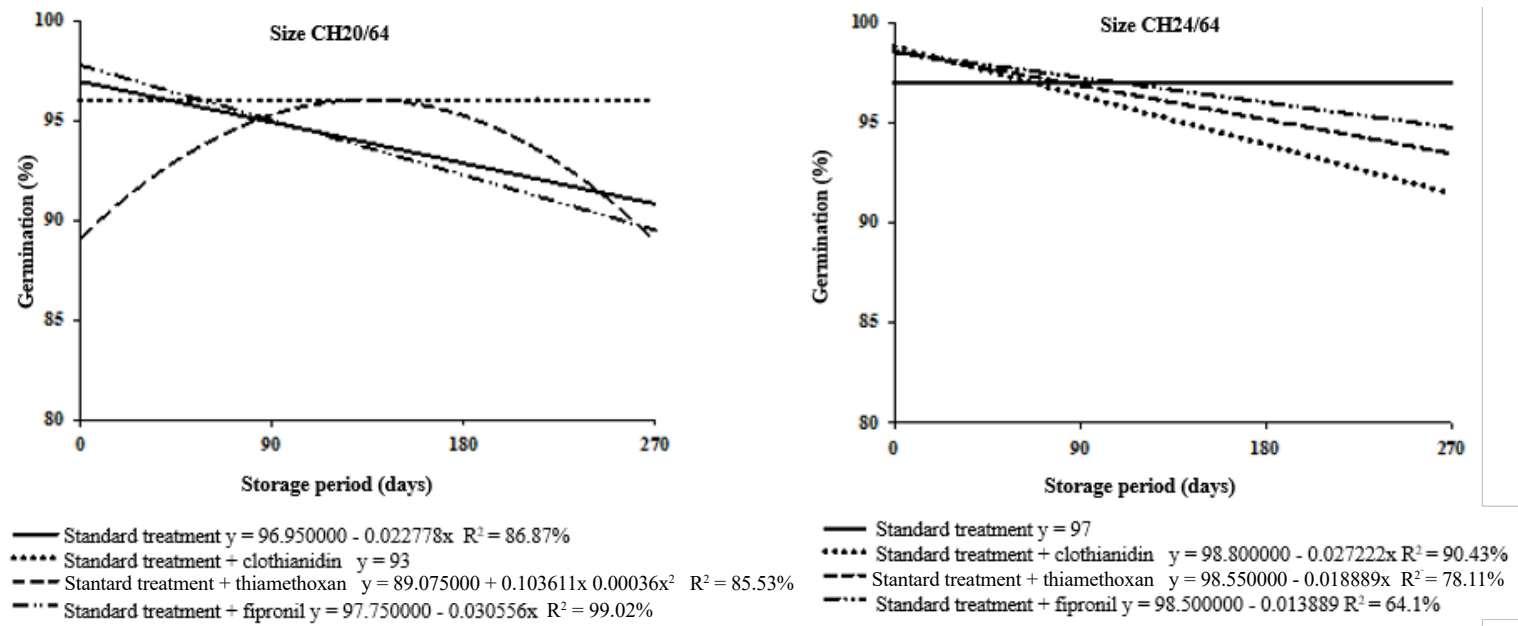

Figure 1. Germination percentage of seeds of the maize hybrid BM915 PRO, sizes $\mathrm{CH} 20 / 64$ and CH24/64, in accordance with storage periods and chemical treatments.

\section{Cold test without soil}

There were no significant effects of the treatments in this test. Bernardi (2015), working with other hybrid, found that treated and stored maize seeds for up to ninety days did not lose physiological performance under the cold test, and seed vigor remained equivalent to that at the beginning of the experimental period.

Horri and Shetty (2007) found that decreases in the viability and vigor of seeds treated with insecticides are not only due to the metabolic changes caused by possible phytotoxic effects of the products, but may also be attributed to damage to cell membranes. Mariucci et al. (2018) likewise observed reduction in vigor of maize seeds treated with the combination of fungicides, insecticides, and inoculants and stored for ninety days.

The query formulated by Hammann (2008) suggests that use of the cold test for vigor evaluation of chemically treated seeds is inappropriate, due to the high number of treated seeds placed per volume of substrate to carry out the test, whether this is conducted in paper or boxes with soil. This would result in a high concentration of active compounds in relation to the true potential for product dilution under field conditions.

Nevertheless, Popinigis (1997) defends the use of the cold test to predict seed performance in the field or in storage, as well as to determine vigor among seed lots and evaluate the effect of fungicide seed treatment. This is because the combination of low temperatures and high humidity is used to allow survival of only the most vigorous seeds, since test conditions can reduce the speed of germination and favor the performance of harmful microorganisms (Marcos-Filho et al., 1987).

\section{Accelerated aging}

There was difference among the chemical treatments at 0 days of storage; the lowest vigor values were observed in seeds under the standard treatment + thiamethoxam. At ninety days, there was no difference among treatments. At 180 and 270 days of storage, the lowest results were attributed to the standard treatment + clothianidin and to the standard treatment + fipronil, respectively (Table 4).

There was no statistical difference in relation to seed size at zero and ninety days of storage (Table 5).

In general, the physiological quality of the seeds declined over the storage period, given the loss of vigor observed in the accelerated aging test, regardless of the chemical treatment used and the size of the seeds (Figures 2 and 3 ). In this test, high temperature and high humidity conditions prevail, which are severe for the seeds and favorable to development of storage fungi, such as Penicillium and Aspergillus, thus leading to a more rapid decline in vigor.

A greater reduction in percentage of germination was observed in seeds of size $\mathrm{CH} 20 / 64$ compared to those of size $\mathrm{CH} 24 / 64$ (Figure 2). 
Table 4. Germination percentage of seeds of the maize hybrid BM915 PRO under accelerated aging in accordance with chemical treatments and storage periods.

\begin{tabular}{ccccc}
\hline \multirow{2}{*}{ Treatment } & \multicolumn{4}{c}{ Storage period (days) } \\
\cline { 2 - 5 } & 0 & 90 & 180 & 270 \\
\hline *Standard treat. & $91 \mathrm{AB}$ & $93 \mathrm{~A}$ & $84 \mathrm{~A}$ & $76 \mathrm{AB}$ \\
*Standard treat + clothianidin & $96 \mathrm{~A}$ & $92 \mathrm{~A}$ & $46 \mathrm{C}$ & $85 \mathrm{~A}$ \\
*Standard treat + thiamethoxam & $85 \mathrm{~B}$ & $86 \mathrm{~A}$ & $73 \mathrm{~B}$ & $79 \mathrm{AB}$ \\
*Standard treat + fipronil & $94 \mathrm{AB}$ & $92 \mathrm{~A}$ & $73 \mathrm{~B}$ & $72 \mathrm{~B}$ \\
\hline CV (\%) & \multicolumn{5}{c}{9.07} \\
\hline
\end{tabular}

Mean values followed by the same uppercase letter in the column do not differ from each other by the Tukey test at $5 \%$ significance.

*Standard treatment.

Table 5. Germination percentage of seeds of hybrid maize BM915 PRO under accelerated aging in accordance with seed size and storage periods.

\begin{tabular}{ccccc}
\hline \multirow{2}{*}{ Seed size } & \multicolumn{5}{c}{ Storage period (days) } \\
\cline { 2 - 5 } & 0 & 90 & 180 & 270 \\
\hline $\mathrm{CH} 20 / 64$ & $92 \mathrm{~A}$ & $89 \mathrm{~A}$ & $76 \mathrm{~A}$ & $73 \mathrm{~B}$ \\
$\mathrm{CH} \mathrm{24/64}$ & $91 \mathrm{~A}$ & $92 \mathrm{~A}$ & $61 \mathrm{~B}$ & $83 \mathrm{~A}$ \\
\hline $\mathrm{CV}(\%)$ & \multicolumn{4}{c}{9.07} \\
\hline
\end{tabular}

Mean values followed by the same uppercase letter in the column do not differ from each other by the Tukey test at $5 \%$ significance.

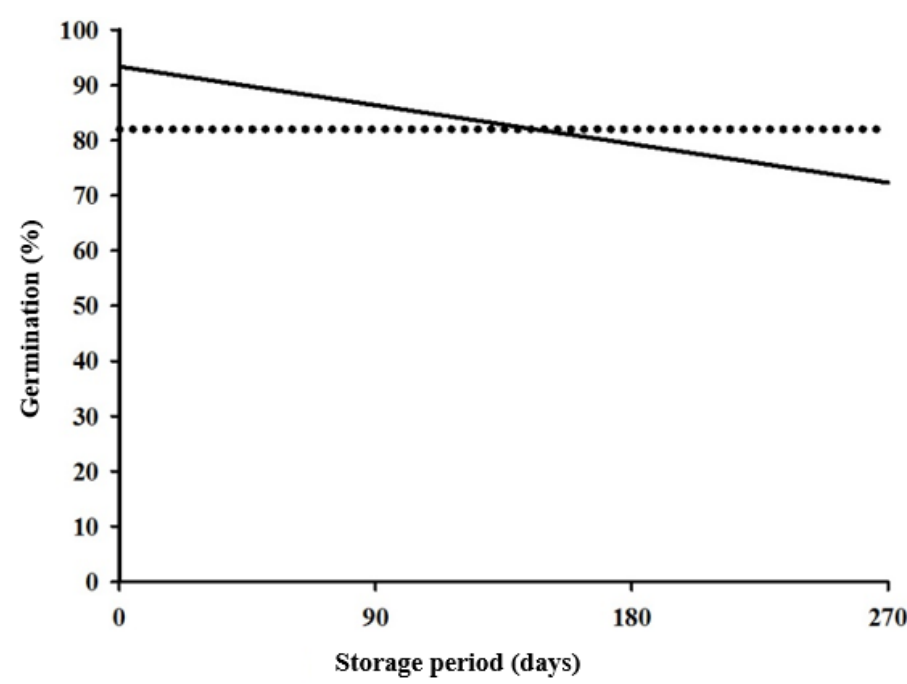

\footnotetext{
Size CH20/64 y $=93.362500-0.07791 \times R^{2}=92.97 \%$

..... Size $\mathrm{CH} 24 / 62$ y $=82$
}

Figure 2. Germination percentage of seeds of the maize hybrid BM915 PRO under accelerated aging in accordance with storage periods and seed size.

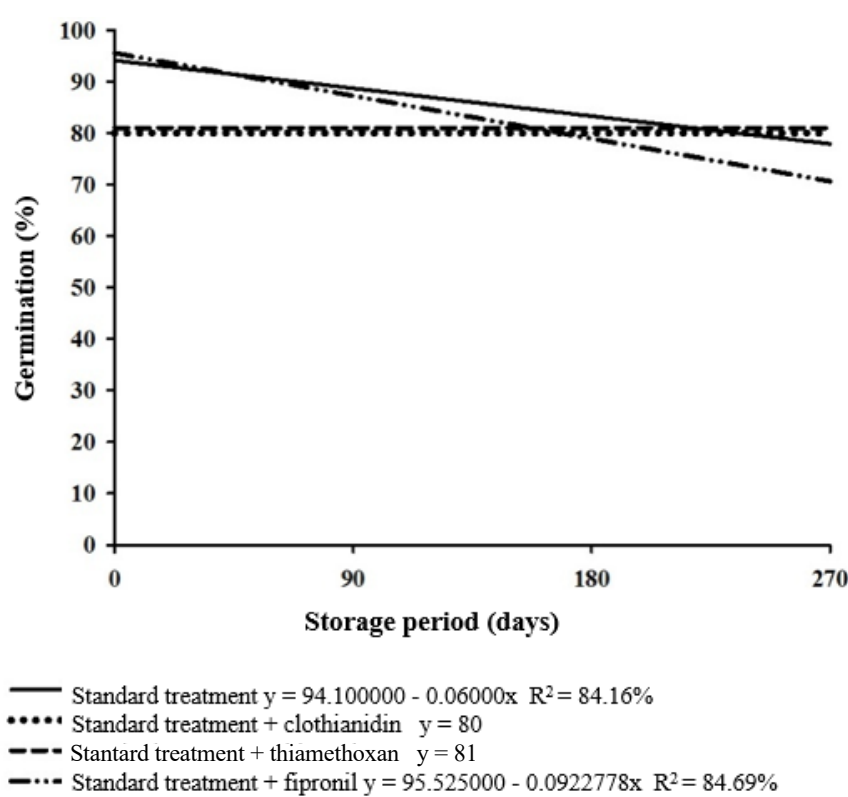

Figure 3. Germination percentage of seeds of the maize hybrid BM915 PRO under accelerated aging in accordance with storage periods and chemical treatments. 
Seed health

In addition to the effects on physiological quality, the standard treatment adopted by the company and the addition of other compounds to the seed chemical treatment did not completely inhibit the occurrence of microorganisms, regardless of the chemical treatment and seed size, and this occurrence was variable throughout the storage period (Table 6).

Fusarium was found in greater quantity in seeds compared to the fungi characteristic of stored grains in the initial period of the experiment (from zero to ninety days). Up to ninety days of storage, there was an increase in the occurrence of the fungi Fusarium, Aspergillus flavus, and Penicillium spp. in the seeds, in all the hybrids used. From that period on, a reduction in these pathogens was observed, even coming to lack of detection in some treatments. The same response was found both for seeds of size $\mathrm{CH} 20 / 64$ and for those of size $\mathrm{CH} 24 / 64$. However, for the seeds of size $\mathrm{CH} 24 / 64$, the reduction in the quantity of pathogens was slower.

Lasca et al. (2005) evaluated the occurrence of fungi in seeds of two maize hybrids under chemical treatment and found greater occurrence of Fusarium verticillioides in seeds of the hybrid Z 8392 (84.75\%), and the second greatest

Table 6. Mean percentage values of the occurrence of fungi in seeds of the maize hybrid BM915 PRO, sizes $\mathrm{CH} 20 / 64$ and $\mathrm{CH} 24 / 64$, in accordance with chemical treatments at $0,90,180$, and 270 days of storage.

\begin{tabular}{|c|c|c|c|c|c|c|c|c|c|c|c|}
\hline \multirow{3}{*}{$\begin{array}{l}\text { Days of } \\
\text { storage }\end{array}$} & \multirow{3}{*}{ Treatment } & \multicolumn{10}{|c|}{ **Fungus (\%) } \\
\hline & & \multicolumn{2}{|c|}{ FU } & \multicolumn{2}{|c|}{$\mathrm{AF}$} & \multicolumn{2}{|c|}{ PE } & \multicolumn{2}{|c|}{ AN } & \multicolumn{2}{|c|}{$\mathrm{AO}$} \\
\hline & & $\mathrm{CH} 20 / 64$ & $\mathrm{CH} 24 / 64$ & $\mathrm{CH} 20 / 64$ & $\mathrm{CH} 24 / 64$ & $\mathrm{CH} 20 / 64$ & $\mathrm{CH} 24 / 64$ & $\mathrm{CH} 20 / 64$ & $\mathrm{CH} 24 / 64$ & $\mathrm{CH} 20 / 64$ & $\mathrm{CH} 24 / 64$ \\
\hline \multirow{4}{*}{0} & *Standard treat. & 77.5 & 85.5 & 3 & 0.5 & 19.5 & 33 & 0 & 0.5 & 1 & 0 \\
\hline & $\begin{array}{l}\text { *Standard treat. } \\
\text { + clothianidin }\end{array}$ & 39 & 48 & 3.5 & 2.5 & 14.5 & 20 & 1 & 1 & 0.5 & 0.5 \\
\hline & $\begin{array}{l}\text { *Standard treat. } \\
+ \text { thiamethoxam }\end{array}$ & 63 & 53.5 & 1.5 & 0 & 17 & 20.5 & 0.5 & 0.5 & 3 & 1.5 \\
\hline & $\begin{array}{l}\text { *Standard treat. } \\
\text { + fipronil }\end{array}$ & 20.5 & 48.5 & 4 & 0 & 18.5 & 19.5 & 0 & 0 & 1.5 & 0.5 \\
\hline \multirow{4}{*}{90} & *Standard treat. & 79 & 48.5 & 3.5 & 1.5 & 40.5 & 41.5 & 0 & 0.5 & 3.5 & 1.5 \\
\hline & $\begin{array}{l}\text { *Standard treat. } \\
\text { + clothianidin }\end{array}$ & 38.5 & 47.5 & 3.5 & 0.5 & 52.5 & 52.5 & 0.5 & 0.5 & 0.5 & 0 \\
\hline & $\begin{array}{l}\text { * Standard treat. } \\
+ \text { thiamethoxam }\end{array}$ & 30 & 54 & 4 & 2 & 36 & 59.5 & 0 & 0 & 3.5 & 1.5 \\
\hline & $\begin{array}{l}\text { *Standard treat. } \\
+ \text { fipronil }\end{array}$ & 75 & 98 & 6.5 & 1 & 47 & 45.5 & 2.5 & 0 & 3.5 & 3.5 \\
\hline \multirow{4}{*}{180} & *Standard treat. & 0 & 0 & 5 & 2 & 8.5 & 7 & 0 & 0 & 0.5 & 0 \\
\hline & $\begin{array}{l}\text { *Standard treat. } \\
\text { + clothianidin }\end{array}$ & 0 & 0 & 6 & 5 & 6.5 & 9 & 0 & 0 & 1 & 0 \\
\hline & $\begin{array}{l}\text { *Standard treat. } \\
+ \text { thiamethoxam }\end{array}$ & 0 & 0 & 4.5 & 3 & 9 & 13.5 & 0 & 0 & 1.5 & 0 \\
\hline & $\begin{array}{l}\text { *Standard treat. } \\
\text { + fipronil }\end{array}$ & 0 & 0 & 1.5 & 1 & 2 & 4.5 & 0 & 1.5 & 0 & 0.5 \\
\hline \multirow{4}{*}{270} & *Standard treat. & 0.5 & 0 & 3.5 & 0 & 0 & 0.5 & 0 & 2 & 0 & 0 \\
\hline & $\begin{array}{l}\text { *Standard treat. } \\
\text { + clothianidin }\end{array}$ & 0 & 0 & 1 & 0.5 & 0.5 & 2 & 0 & 0 & 0 & 0 \\
\hline & $\begin{array}{l}\text { *Standard treat. } \\
+ \text { thiamethoxam }\end{array}$ & 0 & 0 & 1.5 & 0.5 & 0 & 0.5 & 0 & 2 & 0 & 0 \\
\hline & $\begin{array}{l}\text { *Standard treat. } \\
\text { + fipronil }\end{array}$ & 0 & 1 & 0 & 0 & 13 & 6.5 & 0 & 1 & 0.5 & 0 \\
\hline
\end{tabular}

**FU - Fusarium; AF - Aspergillus flavus; PE - Penicillium spp.; AN - Aspergillus niger; AO - Aspergillus ochraceus.

*Standard treatment. 
in the hybrid DAS 9560 (61.50\%). According to Galperin et al. (2003), this fungus is widely disseminated and can cause considerable damage to the maize crop. However, it has been shown that the fungi Fusarium verticillioides, Penicillium sp., and Aspergillus sp. found in the seeds used in this study generally do not affect germination of maize seeds under normal sowing conditions (Pinto, 1996).

In general, it was observed that the mixture of insecticides with the standard treatment did not negatively affect the action of the fungicide on the pathogens.

\section{CONCLUSIONS}

The physiological quality of the maize hybrid seeds BM915 PRO is maintained up to ninety days of storage, regardless of the chemical treatment used and the size of the seeds.

Addition of the insecticide to the standard treatment used in seed chemical treatment does not affect the action of the fungicides on the fungi present in the seeds.

\section{ACKNOWLEDGMENTS}

The authors thank the Conselho Nacional de Desenvolvimento Científico e Tecnológico (CNPq), the Coordenação de Aperfeiçoamento de Pessoal de Nível Superior (CAPES), and the Fundação de Amparo à Pesquisa de Minas Gerais (FAPEMIG) for granting scholarships.

\section{REFERENCES}

BERNARDI, D.; ROCHA, D.M.; BERNARDI, V.H. Influência de inseticidas sobre a germinação e vigor de sementes de milho após armazenamento. Journal of Agronomic Sciences, v.4, n.1, p.53-61, 2015. http://www.dca.uem.br/V4N1/06-Daiane.pdf

BITTENCOURT, S.R.M.; FERNANDES, M.A.; RIBEIRO, M.C.; VIEIRA, R.D. Desempenho de sementes de milho tratadas com inseticidas sistêmicos. Revista Brasileira de Sementes, v.22, n.2 p.86-93, 2000. https://www.abrates.org.br/files/ artigos/58984c51515df1.07068080_artigo12.pdf

BRASIL. Ministério da Agricultura, Pecuária e Desenvolvimento. Manual de análise sanitária de sementes. Ministério da Agricultura, Pecuária e Abastecimento. Secretaria de Defesa Agropecuária. Brasília: MAPA/ACS, 2009a. 202p. http://www.agricultura.gov.br/ assuntos/insumos-agropecuarios/insumos-agricolas/sementes-e-mudas/publicacoes-sementes-e-mudas/manual-de-analisesanitaria-de-sementes/view

BRASIL. Ministério da Agricultura, Pecuária e Desenvolvimento. Regras para análise de sementes. Ministério da Agricultura, Pecuária e Abastecimento. Secretaria de Defesa Agropecuária. Brasília: MAPA/ACS, 2009b. 395p. http:// www.agricultura.gov.br/ arq_editor/file/2946_regras_analise_sementes.pdf

FERREIRA, D.F. Sisvar: a computer statistical analysis system. Ciência e Agrotecnologia, v.35, n.6, p.1039-1042, 2011. http://www. scielo.br/scielo.php?script=sci_arttext\&pid=S1413-70542011000600001

GALPERIN, M.; GRAF, S.; KENIGSBUCK, D. Seed treatment presents vertical transmission of Fusarium moniliforme, making a significant contribution to disease control. Phytoparasitica, v.31, n.4, p.344-352, 2003. https://link.springer.com/article/10.1007/ BF02979805

HAMMANN, B. Comunicação pessoal. Stein: Syngenta, 2008.

HORRI, P.M.; SHETTY, K. Enhancement of seed vigour following insecticide and phenolic elicitor treatment. Bioresource Technology, v.98, n.3, p.623-632, 2007. https://www.sciencedirect.com/science/article/pii/S0960852406000691

KRZYZANOWSKI, F.C.; VIEIRA, R.D.; FRANCA-NETO, J.B. (ed.). Vigor de sementes: conceitos e testes. Londrina: ABRATES, 1999.

LASCA, C.C.; VECHIATO, M.H.; FANTIN, G.M.; KOHARA, E.Y. Efeito do tratamento químico de sementes de milho sobre a emergência e a produção. Arquivo do Instituto de Biologia, v.72, n.4, p.461-468, 2005. http://www.biologico.sp.gov.br/uploads/docs/arq/ v72_4/lasca.PDF 
LORENZETTI, E.R.; RUTZEN, E.R.; NUNES, J.; CREPALLI, M.S.; LIMA, P.H.P.; MALFATO, R.A.; OLIVEIRA, W.C. Influência de inseticidas sobre a germinação e vigor de sementes de milho após armazenamento. Cultivando o Saber, v.7, n.1, p.14-23, 2014. https://www. fag.edu.br/upload/revista/cultivando_o_saber/5399b51186157.pdf

MACHADO, J.C. Tratamento de sementes no controle de doenças. Lavras: UFLA, 2000.

MARCOS-FILHO, J.; CICERO, S.M.; SILVA, W.R. Avaliação da qualidade das sementes. Piracicaba: ESALQ, 1987. 230p.

MARCOS-FILHO, J. Fisiologia de sementes de plantas cultivadas. 2. ed. Londrina: ABRATES, 2015. 660p.

MARIUCCI, G.E.G.; SUZUKAWA, A.K.; BRACCINI, A.L.; SCAPIM, C.A.; LIMA, L.H.S.; ANGELOTTI, P.; PONCE, R.M.; MARTELI, D.C.V. Physiological potential of maize seeds submitted to different treatments and storage periods. Journal of Seed Science, v.40, n.1, p.60-66, 2018. http://www.scielo.br/scielo.php?pid=S2317-15372018000100060\&script=sci_abstract\&tlng=pt

NUNES, J.C.S. Tratamento de sementes de soja como um processo industrial no Brasil. Seed News, v.20, n.1, 2016. https://seednews. com.br/edicoes/artigo/334-tratamento-de-sementes-de-soja-como-um-processo-industrial-no-brasil-edicao-janeiro-2016

NUNES, J.R.G.; MENEZES, N.L.; CARGNELUTTI-FILHO, A. Qualidade fisiológica de sementes de sorgo silageiro submetidas a diferentes sequências de beneficiamento. Pesquisa Agropecuária Gaúcha, v.15, n.1, p.21-28, 2009. http://www.fepagro.rs.gov.br/ upload/1398783827_art03.pdf

PINTO, N.F.J.A. Tratamento fungicida de sementes de milho. In: Simpósio Brasileiro de Patologia de Sementes. Campinas: Fundação Cargill, 1996. p.52-57.

POPINIGIS, F. Fisiologia da semente. Brasília: AGIPLAN, 1997. 287p.

ROSA, K.C.; MENEGHELLO, G.E.; QUEIROZ, E.S.; VILLELA, F.A. Armazenamento de sementes de milho híbrido tratadas com tiametoxam. Informativo ABRATES, v.22, n.3, p.60-65, 2012.

SALGADO, F.H.M.; XIMENES, P.A. Germinação de sementes de milho tratadas com inseticidas. Journal of Biotechnology and Biodiversity, v.4, n.1, p.49-54, 2013. https://www.researchgate.net/publication/250613046_Germinacao_de_sementes_de_ milho_tratadas_com_inseticidas

TONIN, R.F.B.; LUCCA-FILHO, O.A.; LABBE, L.M.B.; ROSSETTO, M. Potencial fisiológico de sementes de milho híbrido tratadas com inseticidas e armazenadas em duas condições de ambiente. Scientia Agropecuaria, v.5, n.1, p.7-16, 2014. http://www.scielo.org. pe/scielo.php?script=sci_arttext\&pid=S2077-99172014000100001 use, distribution, and reproduction in any medium, provided the original work is properly cited. 